\title{
ANALISIS FAKTOR PENTINGNYA PENGETAHUAN IBU TENTANG PENDIDIKAN SEKS DINI
}

\author{
Widia Shofa Ilmiah $^{1)}$, Nina Sukma Amelia ${ }^{2)}$, Fifin Maulidatul Azizah ${ }^{3)}$ \\ Program Studi DIV Kebidanan, STIKES Hafshawaty Pesantren Zainul Hasan \\ email:widiailmiah86@gmail.com
}

\begin{abstract}
Abstrak
Kasus pelecehan seksual anak di Indonesia memasuki fase darurat. Data Komisi Perlindungan Anak (KPA) di Indonesia sekitar $12 \%$ dari seluruh anak di dunia mengalami kekerasan seksual, di Indonesia tahun 2016 sebanyak 120 kasus, tahun 2017 sebanyak 116 kasus, tahun 2018 sebanyak 149 kasus, di Jawa Timur tahun 2017 sebanyak 393 kasus, Februari 2018 sebanyak 117 kasus, Kabupaten Probolinggo pada Januari-April tahun 2016 sebanyak 35 kasus. Hasil studi pendahuluan 16 Agustus 2018 kepada 16 ibu di TK dan PAUD Sumber secang, Condong diketahui $69 \%$ kesulitan menjawab pertanyaan anak tentang seksualitas. Tujuan penelitian melakukan analisis faktor pentingnya pengetahuan ibu tentang pendidikan seks dini. Desain pra eksperimental pre post test group design, populasi seluruh ibu anak di PAUD dan TK Desa Sumber Secang, Condong sebanyak 234 orang, sampel 146 orang, simple random sampling, instrumen kuesioner, lembar observasi, analisis data wilcoxon match paired test. Hasil penelitian 74,7\% ibu memiliki usia 25-40 tahun, 41,1\% SMP, dan 64,4\% sebagai ibu rumah tangga, hasil pre test diketahui 40,4\% ibu memiliki tingkat pengetahuan kurang baik tentang pendidikan seks dini (mean=6,28) dan 40,4\% ibu memiliki tingkat pengetahuan baik sesudah intervensi (mean=9,80). Hasil analisis diperoleh $p=0,000<\alpha 0,05$. Kesimpulan penelitian terdapat pengaruh tingkat pengetahuan ibu sebelum dan sesudah diberikan intervensi berupa pendidikan kesehatan dengan AVA dan faktor yang mempengaruhinya meliputi usia, tingkat pendidikan dan pekerjaan ibu. Perlunya peran kedua yaitu ayah, pengasuh dalam memberikan pendidikan seks dini pada anak bagi ibu yang bekerja di luar rumah dan pentingnya integrasi pendidikan seks pada kurikulum pembelajaran.
\end{abstract}

Kata kunci : faktor, pengetahuan, pendidikan seks dini, ibu

\begin{abstract}
Child sexual violence cases in Indonesia enter emergency phase. Data on Child Protection Commission (KPA) in Indonesia about 12\% of all children in the world experiencing sexual violence, in Indonesia 2016 were 120 cases, 2017 were 116 cases, 2018 were 149 cases, in East Java 2017 were 393 cases, February 2018 were 117 cases, Probolinggo District in JanuaryApril 2016 were 35 cases. Preliminary study 16 August 2018 of 16 mothers in Kindergarten, Early School Education Sumber Secang,Condong village were 69\% difficulty to answer children's questions about sexuality. The aims to analyse importance factors of mother's knowledge of early sex education. Pre experimental design pre post test group design, the population of all mother children in Kindergarten and Early School Education in Sumber Secang, Condong were 234 people, samples were 146 people, simple random sampling, questionnaire, observation sheet, analysis Wilcoxon match paired test. The results study $74.7 \%$ of mothers have age 25-40 y.o, 41.1\% junior high school, 64.4\% as housewives, pre test results were $40.4 \%$ mothers have low level of knowledge (mean =6.28), 40.4\% of mothers have good level of knowledge after the intervention (mean $=9.80$ ), $p=0,000<\alpha 0.05$. The conclusion have the influence of mothers knowledge level before and after intervention by AVA and factors that affect it include age, education level, employment. The need for a second roles are father, caregiver in providing early sex education to children for mothers working outdoors and importance to integrate of sex education on learning curriculum.
\end{abstract}

Keywords: factor, knowledge, early sex education, mother 


\section{PENDAhUluaN}

Pendidikan seks merupakan suatu pengetahuan yang kita ajarkan mengenai segala sesuatu terkait jenis kelamin, pertumbuhan jenis kelamin (laki-laki dan perempuan), fungsi alat reproduksi, dan lainnya (Astuti, Sugiyatno dan Aminah, 2017). Permasalahan terkait seksualitas dapat terjadi pada anak usia dini antara 0-6 tahun. Usia dini merupakan periode penting pembentukan perilaku dan orientasi seks pada masa remajanya nanti. Hal ini dapat berpengaruh langsung dalam kehidupan seksualnya (Zhina, 2013 dan Anggraini, 2017).

Kasus kekerasan atau pelecehan seksual pada anak di Indonesia telah memasuki fase darurat. Data yang tercatat tentang kekerasan seksual pada anak hanya berdasarkan kasus yang dilaporkan dengan jumlah setiap tahunnya semakin meningkat sehingga masalah kekerasan seksual pada anak masih seperti fenomena gunung es (Nurvianti, 2016).

Berdasarkan Data Komisi Perlindungan Anak (KPA) di Indonesia bahwa sekitar $12 \%$ dari seluruh jumlah anak di dunia mengalami kekerasan seksual dan di Indonesia sendiri pada tahun 2016 sebanyak 120 kasus kekerasan seksual pada anak dan tahun 2017 sebanyak 116 kasus serta pada tahun 2018 sebanyak 149 kasus. Data kekerasan seksual di Jawa Timur tahun 2017 sebanyak 393 kasus dan pada Februari 2018 sebanyak 117 kasus. Data Lembaga Perlindungan Anak (LPA) Kabupaten Probolinggo mulai bulan Januari-April tahun 2016 ditemukan 35 kasus. Berdasarkan data tersebut diketahui pelakunya sebagian besar adalah orang terdekat anak yaitu ayah tiri dan kandung serta tetangga.

Pendidikan seks yang tidak diberikan di usia dini mengakibatkan tingginya kekerasan seksual pada anak oleh orang-orang terdekat anak termasuk keluarga, kurangnya pengetahuan tentang cara memberikan pendidikan seks yang benar pada anak oleh ibu, orientasi ketertarikan seksual kepada anak-anak (pedofilia), pengaruh pornomedia massa (media yang menampilkan hal-hal bersifat porno) dan ketidakpahaman anak terhadap persoalan seksualitas (Noeratih, 2016). Selain itu, masalah seksualitas di kalangan masyarakat masih dianggap tabu (Nurvianti, 2016). Akibat yang ditimbulkan meliputi rasa trauma secara fisik, psikis seperti gangguan rasa percaya diri, stres, depresi, masalah sosial seperti dapat menjadi pelaku pedofilia pada masa dewasanya nanti, meingkatkan kasus prostitusi pada usia anakanak serta semakin meningkatnya tindak kriminalitas seperti kasus pembunuhan (Paramastri dan Priyanto, 2010). Selanjutnya akibat lainnya yaitu adanya rasa bersalah dan menyalahkan diri sendiri, sering mengingat kejadian dimana ia menerima tindak kekerasan seksual, gangguan tidur, serta adanya rasa takut dengan berbagai hal yang berhubungan dengan bau, benda, tempat bahkan kunjungan petugas kesehatan (Diana, 2017).

Hasil studi pendahuluan yang dilakukan peneliti pada 16 Agustus 2018 kepada $16 \mathrm{ibu}$ yang terdiri dari 6 ibu anak pra sekolah di PAUD dan TK Raudatul Hasan dan 5 ibu di TK Harapan Kita Desa Condong serta 5 ibu di TK Al Hidayah Sumber Secang dengan cara wawancara tentang masalah seksual meliputi kenapa dia memiliki jenis kelamin mereka berbeda dengan temannya, dia berasal dari mana, kenapa laki-laki dan atau perempuan memakai baju yang berbeda, dan tentang fungsi anggota badan. Hasilnya dari 16 ibu menunjukkan sebanyak 11 ibu (69\%) kesulitan menjawab pertanyaan anak mereka tentang pertanyaan dari mana ia berasal, kenapa ia memiliki jenis kelamin yang berbeda serta tentang fungsi anggota badan.

Upaya pencegahan kekerasan seksual dan eksploitasi seksual dilakukan dengan memberikan pendidikan seks yang benar sesuai usia anak oleh orang terdekat yaitu ibu. Pendidikan seks dini pada anak sebaiknya diberikan sejak anak usia 4-6 tahun (Sulistianingsih dan Widayati, 2016). Pendidikan seks pada tahap awal dapat dilakukan dengan mengajarkan konsep benarsalah, mengajarkan cara menjaga diri sendiri, menjaga kebersihan badan, cara berinteraksi dengan orang lain serta cara mendidik perilaku anak tentang seks. Pengetahuan, sikap, keterampilan ibu dalam berkomunikasi, memiliki peran penting dalam perilaku seksual dan orientasi seks yang benar serta bertanggungjawab pada anak pra sekolah (Mobredi, Batool and Azghady, 2018). Hal ini sesuai dengan penelitian (Pujiastuti dan Nurrohmah, 2016) tentang Karakteristik Ibu Dalam Penerapan Pendidikan Seks Anak Usia Dini di TK MDI 1 Garen Kecamatan Ngemplak Boyolali bahwa pendidikan, pekerjaan, pengetahuan berhubungan dengan kemampuan penerapan pendidikan seks anak usia dini. 
Tujuan penelitian ini yaitu melakukan analisis faktor pentingnya pengetahuan ibu tentang pendidikan seks dini.

\section{METODE PENELITIAN}

Penelitian ini menggunakan desain pra eksperimental dengan jenis pre post test group design. Populasi penelitian ini yaitu seluruh ibu anak pra sekolah PAUD dan TK di Desa Condong dan Desa Sumber Secang Kabupaten Probolinggo sebanyak 234 orang. Sampel penelitian ini sejumlah 146 orang. Sampling penelitian menggunakan simple random sampling. Variabel bebas penelitian ini yaitu pemberian pendidikan kesehatan tentang pendidikan seks dini dengan menggunakan media audio visual dan variabel terikat penelitian ini yaitu tingkat pengetahuan. Pengumpulan data penelitian ini menggunakan instrument lembar kuesioner dan lembar observasi dan analisis data menggunakan wilcoxon match paired test. Penelitian ini telah dilakukan kaji etik oleh Komisi Etik STIKes Hafshawaty Pesantren Zainul Hasan dengan nomor SK. KEPK 064/STIKes-PZH/IV/2019.

\section{HASIL DAN PEMBAHASAN}

\section{Hasil}

Tabel 1. Faktor Demografi

\begin{tabular}{|c|c|c|}
\hline Faktor Demografi & n & $\%$ \\
\hline \multicolumn{3}{|l|}{ Umur (Tahun) } \\
\hline 18-24 & 19 & 13.0 \\
\hline $25-40$ & 109 & 74.7 \\
\hline 41-59 & 17 & 11.6 \\
\hline$\geq 60$ & 1 & 0.7 \\
\hline \multicolumn{3}{|l|}{ Skor rata-rata 32,18} \\
\hline \multicolumn{3}{|l|}{ Tingkat Pendidikan } \\
\hline SD & 39 & 26.7 \\
\hline SMP & 60 & 41.1 \\
\hline SMA & 39 & 26.7 \\
\hline PT & 8 & 5.5 \\
\hline \multicolumn{3}{|l|}{ Pekerjaan } \\
\hline IRT & 94 & 64.4 \\
\hline Buruh & 8 & 5.5 \\
\hline Petani & 22 & 15.1 \\
\hline Wiraswasta & 11 & 7.5 \\
\hline Swasta & 8 & 5.5 \\
\hline PNS & 3 & 2.1 \\
\hline
\end{tabular}

Berdasarkan tabel 1 diketahui bahwa 109 ibu $(74,7 \%)$ memiliki usia antara 25-40 tahun, 60 ibu $(41,1 \%)$ memiliki pendidikan
SMP, dan 94 ibu $(64,4 \%)$ memiliki status pekerjaan sebagai ibu rumah tangga.

Tabel 2. Distribusi Frekuensi Tingkat Pengetahuan Sebelum Pemberian Pendidikan Seks Dini

\begin{tabular}{|c|c|c|}
\hline $\begin{array}{c}\text { Tingkat Pengetahuan } \\
\text { Sebelum }\end{array}$ & $\mathbf{n}$ & $\%$ \\
\hline 1-3 (Sangat Kurang Baik) & 24 & 16,4 \\
\hline 4-6 (Kurang Baik) & 59 & 40,4 \\
\hline 7-9 (Cukup Baik) & 42 & 28,8 \\
\hline 10-12 (Baik) & 19 & 13,0 \\
\hline 13-15 (Sangat Baik) & 2 & 1,4 \\
\hline Jumlah & 146 & 100 \\
\hline Mean $=6,28$ & & \\
\hline
\end{tabular}

Berdasarkan tabel 2 diketahui bahwa 59 ibu $(40,4 \%)$ memiliki tingkat pengetahuan kurang baik tentang pendidikan seks dini sebelum diberikan pendidikan kesehatan dengan rata-rata tingkat pengetahuannya yaitu 6,28 .

Tabel 3. Distribusi Frekuensi Tingkat Pengetahuan Sesudah Pemberian Pendidikan Seks Dini

\begin{tabular}{lcc}
\hline \multicolumn{1}{c}{$\begin{array}{c}\text { Tingkat Pengetahuan } \\
\text { Sesudah }\end{array}$} & n & $\%$ \\
\hline 1-3 (Sangat Kurang Baik) & 0 & 0 \\
4-6 (Kurang Baik) & 17 & 11,6 \\
7-9 (Cukup Baik) & 50 & 34,2 \\
10-12 (Baik) & 59 & 40,4 \\
13-15 (Sangat Baik) & 20 & 13,7 \\
\hline \multicolumn{1}{c}{ Jumlah } & 146 & 100 \\
\hline \multicolumn{2}{c}{ Mean $=\mathbf{9 , 8 0}$} & \\
\hline
\end{tabular}

Berdasarkan data tabel 3 diketahui bahwa 59 ibu $(40,4 \%)$ memiliki tingkat pengetahuan baik tentang pendidikan seks dini sesudah diberikan pendidikan kesehatan dengan rata-rata tingkat pengetahuannya yaitu 9,80 .

Hasil analisis bivariat dengan Wilcoxon Match Paired Test diperoleh $\mathrm{p}=0,000$.

\section{Pembahasan}

Berdasarkan hasil penelitian menunjukkan bahwa tingkat pengetahuan sebelum diberikan pendidikan kesehatan diketahui kurang baik dan tingkat pengetahuan setelah diberikan pendidikan kesehatan menggunakan media audio visual 
(AVA) sebagian besar ibu anak pra sekolah memiliki tingkat pengetahuan baik.

Pendidikan kesehatan adalah sebuah proses pemberian informasi tentang kesehatan kepada masyarakat (Ilmiah et al., 2019) Media yang dapat digunakan dalam memberikan pendidikan kesehatan yaitu lagu, alat permainan seperti boneka, puzzle, permaninan pasir, filp chart, poster, video (Haryono et al., 2018). Faktor yang mempengaruhi keberhasilan pendidikan kesehatan yaitu ketepatan waktu, sasaran, materi menarik.

Tingkat pengetahuan adalah sebuah hasil yang diperoleh individu setelah mereka melakukan penginderaan terhadap sebuah obyek. Faktor yang mempengaruhi tingkat pengetahuan yaitu faktor internal meliputi umur, tingkat pendidikan, pekerjaan, ras, status sosial ekonomi, sedangkan faktor eksternal meliputi kondisi lingkungan rumah, lingkungan sekolah dan pergaulan teman sebaya, faktor budaya (Ilmiah et al., 2019). Tingkat pengetahuan ibu tentang pemberian pendidikan seks dini yang benar sesuai usia anak menjadi hal yang sangat penting untuk membuka komunikasi antara anak dengan ibu tentang seksualitas dengan menggunakan bahasa yang sesuai usia anak (Saskatchewan, 2017).

Menurut (Ilmiah et al., 2019), pemberian intervensi berupa pendidikan kesehatan atau pemberian informasi kesehatan tentang pendidikan seks dini menggunakan media audio visual (AVA) terbukti meningkatkan pengetahuan ibu sebelum dan sesudah intervensi.

Faktor pertama yang mempengaruhi tingkat pengetahuan yaitu usia. Usia merupakan faktor demografi yang dapat mempengaruhi pengetahuan responden. Hasil penelitian peneliti pada tabel 1 menunjukkan bahwa 74,7\% ibu anak pra sekolah memiliki usia 25-40 tahun. Menurut (Desmita, 2014) usia seseorang dapat mempengaruhi proses pendewasaan dan pengalaman. Pada level usia 25-40 tahun dengan kategori dewasa muda diketahui memiliki karakteristik mudah menerima berbagai informasi dari berbagai jenis sumber informasi termasuk hal yang berkaitan dengan seksualitas. Hal ini sesuai dengan hasil penelitian (Meilani et al., 2014) bahwa semakin tua usia responden akan memiliki pengetahuan dan perilaku baik dalam memberikan pendidikan seksual pada anaknya.

Selanjutnya faktor tingkat pendidikan. Sesuai hasil penelitian peneliti pada tabel 1 bahwa tingkat pendidikan responden sebagian besar adalah SMP. Tingkat pendidikan SMP merupakan level pendidikan yang masih rendah, sehingga proses pemberian informasi dari luar sangat dibutuhkan. Pada level pendidikan SMP, responden sudah lebih mudah menerima informasi dan menerapkan infromasi yang diperoleh dibandingkan dengan mereka yang memiliki tingkat pendidikan SD, meskipun beberapa diantara mereka mengalami kesulitan dalam menyerap informasi dengan cepat. Hal ini sesuai dengan hasil penelitian (Anindita, 2017) bahwa semakin tinggi tingkat pendidikan seseorang akan mempermudah penerimaan mereka terhadap sebuah informasi baru yang diperoleh, dan semakin tinggi tingkat pendidikan akan meningkatkan kesadaran mereka untuk mencari tau sebuah informasi, dalam hal ini tentang seksualitas.

Sedangkan faktor pekerjaan berdasarkan hasil penelitian pada tabel 1 diketahui bahwa sebagian besar responden memiliki pekerjaan sebagai ibu rumah tangga (IRT). Status pekerjaan sebagai status sosial ekonomi merupakan sebuah profesi tetap yang ditekuni oleh ibu. Pekerjaan menurut (Pandia, Widyawati and Indriati, 2017) dapat mempengaruhi secara tidak langsung pengetahuan ibu tentang seksualitas. Ibu yang tidak bekerja atau hanya sebagai ibu rumah tangga diketahui memiliki waktu luang lebih banyak dibandingkan dengan ibu yang bekerja di luar rumah. Ibu rumah tangga memungkinkan memiliki waktu luang lebih banyak untuk secara mandiri mengakses berbagai informasi termasuk tentang pendidikan seks dini. Akan tetapi ketepatan dalam mengakses informasi dan penerapannya diperlukan sumber informasi yang tepat yang tidak semuanya dapat dipahami secara mandiri melalui media sosial dan elektronik. Oleh karena itu, peran petugas kesehatan, guru kelas menjadi penting dalam membantu ibu memberikan 
pendidikan kesehatan tentang seks dini pada anaknya ketika ibu mengantar anak ke sekolah.

\section{KESIMPULAN DAN SARAN}

\section{Kesimpulan}

Intervensi berupa pemberian pendidikan kesehatan tentang pendidikan seks dini pada anak pra sekolah diketahui berpengaruh terhadap tingkat pengetahuan ibu tentang seksualitas sebelum dan sesudah diberikan pendidikan kesehatan. Akan tetapi, terdapat beberapa faktor lainnya yang mempermudah penyerapan informasi yang diberikan kepada ibu tentang pendidikan seks dini yaitu faktor usia ibu, tingkat pendidikan dan status pekerjaan ibu. Semakin dewasa usia ibu maka akan semakin matur dan semakin mudah menyerap informasi yang diberikan. Demikian juga semakin tinggi tingkat pendidikan ibu, maka akan semakin mudah

\section{REFERENSI}

Anggraini, T. (2017). Pendidikan Seks untuk Anak Usia 4-5 Tahun di PAUD IT Qurrota A'Yun Kota Bandar Lampung. Universitas Lampung.

Anindita, P. R. (2017). Pengaruh penyuluhan pendidikan seksual dini terhadap tingkat pengetahuan pada ibu di TK Aba Wirobrajan I dan II Yogyakarta. 'Aisyiyah.

Astuti, B., Sugiyatno, S. and Aminah, S. (2017). 'The Development of Early Childhood Sex Education Materials for Early Childhood Education ( ECE ) Teachers', Jurnal Pendidikan dan Pemberdayaan Masyarakat, 4(2), pp. 113-120.

Desmita. (2014). Psikologi Perkembangan Peserta Didik. Bandung: PT. Remaja Rosdakarya.

Diana, N. (2017). 'Decicion Making Sebagai Solusi Kekerasan Terhadap Anak Melalui Play Therapy', Jurnal Bimbingan dan Konseling, 04(23), pp. 13-22. dalam menerima informasi yang diberikan dan status pekerjaan ibu yang memiliki waku luang lebih banyak dalam mengasuh anak, akan lebih mudah memperolah informasi tentang pendidikan seks dini untuk anak dari berbagai sumber informasi baik guru, petugas kesehatan dan media cetak atau elektronik.

\section{Saran}

Diperlukannya penelitian lebih lanjut tentang variabel lainnya yang belum diteliti seperti sikap, budaya, keterampilan, faktor penghambat dan pendukung keberhasilan intervensi. Selain itu, perlunya peran kedua selain ibu, yaitu ayah atau pengasuh anak dalam membantu memberikan pendidikan seks dini pada anaknya khususnya bagi ibu yang bekerja di luar rumah yang memiliki waktu terbatas untuk kontak dengan anak dan perlunya integrasi pendidikan seks dini anak dengan kurikulum pembelajaran di Sekolah.

Haryono, S. E. et al. (2018). 'Implemetasi Pendidikan Sex Pada Anak Usia Dini di Sekolah Sarah', Jurnal Akses Pengabdian Indonesia, 3(1), pp. 24-34.

Ilmiah, WS. et al. (2019). 'Pengaruh Pelatihan Pendidikan Seks Anak Pra Sekolah Dengan Media Audio Visual Terhadap Pengetahuan Ibu', Conference on Research \& Community Services, pp. 226-231.

Meilani, N. et al. (2014). 'Perilaku Ibu dalam Memberikan Pendidikan Seksualitas pada Remaja Awal The Mother's Behavior in Sexual Education for Early Adolescent', Jurnal kesehatan Masyarakat Nasional, 8(8), pp. 411417.

Mobredi, K., Batool, S. and Azghady, H. (2018). 'Effect of the Sexual Education Program on the Knowledge and Attitude of Preschoolers ' Mothers', Journal of Clinical and Diagnostic Research, 12(6), pp. 6-9. doi: 10.7860/JCDR/2018/32702.11616. 
Noeratih, S. (2016). Peran Orang Tua terhadap Pendidikan Seks untuk Anak Usia 4-6 Tahun (Studi di Desa Wanakaya Jawa Barat). Universitas Negeri Semarang.

Nurvianti, E. K. A. (2016). 'Faktor-Faktor Yang Berhubungan Dengan Praktek Penerapan Pendidikan Kesehatan Reproduksi Oleh Orang Tua Pada Anak Usia Dini di Paud LabSchool UNNES', repository unimus, pp. 121.i

Pandia, W. S. S., Widyawati, Y. and Indriati, E. (2017). 'Sexual Education Knowledge for Early Childhood', Advances in Social Science, Education and Humaniti

Paramastri, I. and Priyanto, M. A. (2010). 'Early Prevention Toward Sexual Abuse on Children', Jurnal Psikologi, 37(1), pp. 1-12.
Pujiastuti, ika R. and Nurrohmah, A. (2016). 'Karakteristik Ibu Dalam Penerapan Pendidikan Seks Anak Usia Dini di TK MDI 1 Garen Kecamatan Ngemplak Boyolali', Maternity: Jurnal Kebidanan dan Ilmu Kesehatan, 3(November), pp. 25-34.

Saskatchewan. (2017).'Parents as Sexual Health Educators for Their Children: A Literature Review', in Parents as Sexual Heath Educators. The Saskatchhewan Institute, pp. 1-35.

Sulistianingsih, A. and Widayati, W. (2016). 'Hubungan Pengetahuan dengan Perilaku Ibu Memberikan Pendidikan Seks pada Anak', Jurnal Ilmiah Kebidanan, 7(2), pp. 34-43.

Zhina, C. (2013). 'A Review of Sex Education for Preschool Children in Mainland China from 1992 to 2012', International review od Social Sciences and Humanities, 5(2), pp. 12-18. 